\title{
Scavenging of atmospheric particulates by snow in Changji, China
}

\author{
Liu Y. ${ }^{1, *}$, Fu B. ${ }^{1}$, Liu C. ${ }^{2}$, Shen Y. ${ }^{2}$, Liu H. ${ }^{3}$, Zhao Z. ${ }^{1}$ and Wei T. ${ }^{2}$ \\ ${ }^{1}$ College of Geography and Environmental science, Hainan Normal University, Haikou, Hainan 571158, China \\ 2Department of Chemistry and Applied Chemistry, Changji University, Changji, Xinjiang 831100, China \\ ${ }^{3}$ Changji Environmental Monitoring Station, Changji, Xinjiang 831100, China \\ Received: 14/12/2017, Accepted: 26/06/2018, Available online: 26/09/2018 \\ *to whom all correspondence should be addressed: e-mail: cjenvironment@126.com \\ https://doi.org/10.30955/gnj.002548
}

\section{Abstract}

Changji is an arid city in the north west of China which suffers from severe air pollution due to increasing vehicle use and heating with coal. Samples (TSP, PM10, PM5, $\mathrm{PM}_{2.5}$ ) were collected before and after several snow events, for revealing the snow scavenging effect and influencing mechanisms. The result indicated that the snow scavenging effect was obvious. The highest snow scavenging quantity and scavenging ratio is TSP, followed by $\mathrm{PM}_{10}, \mathrm{PM}_{5}$ and $\mathrm{PM}_{2.5}$. Snow scavenging quantity was dependent on the particulate diameter. Snow intensity, drying time and amount of snow influenced scavenging ratio, and snow intensity is the key influencing factor. Scavenging ratio increases with the increase of snow intensity. Higher snow intensity can reduce the selective scavenging of particulate diameters, the scavenging ratio of different particulate diameter will get close to each other. The lower snow intensity was, the higher selectivity was. Light snow will scavenge large particles obviously, but little for small particle.

Keywords: atmospheric particulates, influencing factors, scavenging, snow.

\section{Introduction}

Total suspended particles (TSP) refers to particles with diameter $<100 \mu \mathrm{m}$ which is an archaic regulatory measurement of mass concentration of particulate matter (PM) in community air. Particulate matter is microscopic solid or liquid particles suspended in the Earth's atmosphere, such as dust, pollen, soot, smoke, and liquid droplets. $\mathrm{PM}_{2.5}, \mathrm{PM}_{5}$ and $\mathrm{PM}_{10}$ refer to particles with diameter $<2.5 \mu \mathrm{m}, 5 \mu \mathrm{m}$ and $10 \mu \mathrm{m}$, respectively. Particulate Matter is one of the most important atmospheric pollutants. PM can easily enrich a variety of chemical substances, such as toxic heavy metals, acidic oxides, organic pollutants, and other toxic substances like bacteria, viruses, and so on, then cause a variety of chronic or unexpected diseases such as respiratory diseases, hypertension, arteriosclerosis, heart disease, and even resulting in death (Chen et al., 2013; Freije, 2015; Gunawardena et al., 2013; Lee and Park, 2010; Singh et al., 2010). Particulate pollution is the leading cause of urban air pollution in China. The synergy of PM and the composition of PM may lead to more severe synergistic toxicological effects (Vijayanand et al., 2008). In recent years, the urban environmental air quality is getting worse, atmospheric particulate matter has become an important research topic (Francová et al., 2016).

Atmospheric particulate pollution is influenced by meteorological conditions. In the circumstances of stable distribution of pollution source and steady emission of pollutant, the concentration of atmospheric particles mainly depends on the transportation and diffusion of particles in various meteorological conditions (Hu et al., 2012; Lima et al., 2014; Liu et al., 2011; Mamtimin et al., 2011; Schleicher et al., 2011; Valiulis et al., 2002). Dry and wet deposition reduces the long-term accumulation of pollutants in the air, then transfer the pollutants to the urban surface (Grantz et al., 2003; Liu et al., 2015). Scavenging is a purified process. Some studies found that the precipitation can scavenge atmospheric particulates obviously. Snow can effectively remove gaseous and particulate pollutants from air (Marusczak et al., 2011; Nazarenko et al., 2017; Shan et al., 2015; Taniyasu et al., 2013; Wania et al., 1998). Snowflakes have larger particlespecific surface, high porosity and slower fall velocity, they can enrich more pollutants than rain. The snowflake is considered to be a more effective scavenger than rain, too (Cereceda-Balic et al., 2012; Francová et al., 2016; Nazarenko et al., 2017). Snow has been proved to be the most relevant indicator of tracing metals and other types of environmental pollutants. Combining snow with $\mathrm{PM}_{10}$ can also provide very useful information for today's pollution assessment (Francová et al., 2016).

Precipitation has a certain effect to scavenge the PM in atmosphere. Most of the studies on scavenging of particulate pollutants are affected by rain (Chate, 2005; Melaku et al., 2008; Liu et al., 2015). A study in Beijing (China) found that the four PMs decreased $80 \%$ after the snow event and snow has certain effect for four PMs (Guo et al., 2013). And the study in Logan (USA) also found that snow can effectively monitored the concentration of four PMs (Malek et al., 2006). The study of scavenging 
mechanism of particulate pollutants by snow is limitedly reported (Nazarenko et al., 2017). Building on that background, the effect and influencing mechanisms of scavenging of atmospheric particulates by snow were analyzed in Changji (Xinjiang, Northwest in China), the snow ordinal represents each snow event. It is of great scientific significance to carry out this study in prevention and control of urban air pollution and ecological environment protection.

\section{Materials and methods}

\subsection{Sampling site}

The measurement campaign took place in Changji, the capital of Xinjiang Uygur Autonomous Region, China, which is a satellite city of Urumqi located on the north slope of the Tianshan Mountains, with a population of 420 thousand. It has a typical continental arid climate. The annual precipitation is only about 183 to $200 \mathrm{~mm}$. The main form of precipitation is snow in winter. The sampling sites were located on the roof of No.4 apartment of Changji College North Campus in Beijing North Road, 12 meters above the ground. The sampling area is near the city centre. Changji has experienced rapid economic growth in recent years. Increasing vehicle use, urban expansion, and heating with coal have resulted in increasing pollutant emissions and degrading air quality. These factors are placing unprecedented pressures on the urban ecological environment.

\subsection{Experimental method}

The sampling period is winter, from November 2016 to March 2017. There are many factors affecting the scavenging of atmospheric particles, such as wind speed, precipitation and so on. This study focuses on the impact of the scavenging of atmospheric particulate matter by snow. Therefore, we only collect samples in gentle breeze days $(12-19 \mathrm{~km} / \mathrm{h})$, and on the date when the wind speed and wind direction keep steady. Seven typical snow events were selected according to the snow pattern. In sampling period, the sampler was powered off suddenly in December $12^{\text {th }}$ 2017. Therefore we abandon the date of December $12^{\text {th }} 2017$, this study is aimed at analyzing the other 7 snow events.

Three Laoying 2030 medium flow rate intelligent TSP samplers (Laoying Institute), a PALL water purification system (Pall, Port Washington, NY, USA) and an electric heating air-blowing drier were used. Samples (TSP, PM10, $\mathrm{PM}_{5}, \mathrm{PM}_{2.5}$ ) were collected before and after each snow event. Each sample of $\mathrm{PM}_{2.5}, \mathrm{PM}_{5}, \mathrm{PM}_{10}$ and TSP was continuously collected on a glass fiber filter for $24 \mathrm{~h}$ using a medium flow rate intelligent TSP sampler at an approximately flow rate of $0.1 \mathrm{~m}^{3} \mathrm{~min}^{-1}$. Weather data (atmospheric pressure, relative humidity, temperature, wind speed, and wind direction) were recorded during the sampling period; the length of drying time was counted, and the snow characteristics such as snowfall, snow intensity and snow duration were monitored with Changji
Meteorological Observatory. Samples were collected on a glass fiber filter with of $90 \mathrm{~mm}$ diameter and $0.65 \mu \mathrm{m}$ aperture. The filters were put into dry dish for $48 \mathrm{~h}$ and weighed before and after sampling. The concentration of atmospheric particulate can be calculated by,

$$
\mathrm{C}=\left(\mathrm{W}_{1}-\mathrm{W}_{0}\right) * 10^{9} /\left(\mathrm{Q}^{*} \mathrm{t}\right)
$$

Where $\mathrm{C}$ is the concentration of atmospheric particulate $\left(\mu \mathrm{g} / \mathrm{m}^{3}\right), W_{0}$ and $W_{1}$ is the quality of the filter before and after the snow, respectively $(\mu \mathrm{g}), \mathrm{Q}$ is sampling flow rate $\left(\mathrm{m}^{3} / \mathrm{min}\right)$, and $\mathrm{t}$ is time ( $\left.\mathrm{min}\right)$.

\section{Results and discussion}

\subsection{Characteristics of sampling snow events}

Snow types are identified from the announcement of Meteorological Administration which evaluates the snow types based on information on $24 \mathrm{~h}$ snow amount (L). Snow types are divided in light snow, moderate snow, heavy snow, and blizzard, the amount of which is $L<2.5$, $2.6<L<4.9,5.0<L<9.9$, and $L>10$, respectively. Consecutive days (2-3 days) of snow is normal in winter in Xinjiang. In this study, consecutive snow events, of which intervals were under $12 \mathrm{~h}$, were defined as a snow event, for consecutive snow had a consecutive scavenging effect of atmospheric particulates. An hourly average snow intensity (HASI) to discuss snow scavenging effect of atmospheric particulates was calculated by using the information on total snow amount of a snow event (TSAASE) and total snow hours of a snow event (TSHASE), i.e., $\operatorname{HASI}(\mathrm{mm} / \mathrm{h})=\mathrm{TSAASE}(\mathrm{mm}) / \operatorname{TSHASE}(\mathrm{h})$. Characteristics of seven snow events were shown in Table 1 , the snow ordinal represents each snow event.

\subsection{Variations of atmospheric particulates concentration before and after snow}

The mean value, standard deviation and range (minimum and maximum, in brackets) of $\mathrm{TSP}, \mathrm{PM}_{10}, \mathrm{PM}_{5}, \mathrm{PM}_{2.5}$ concentration before snow was 286.31 \pm 70.22 (414.59203.47) $\mathrm{\mu g} / \mathrm{m}^{3}, \quad 251.89 \pm 75.47(400.01-168.06) \mathrm{\mu g} / \mathrm{m}^{3}$, $225.30 \pm 72.74 \quad(353.48-138.89) \mu \mathrm{g} / \mathrm{m}^{3}, \quad 192.16 \pm 61.66$ (282.64-109.03) $\mathrm{\mu g} / \mathrm{m}^{3}$, respectively. The mean value and range (minimum and maximum, in brackets) of TSP, $\mathrm{PM}_{10}$, $\mathrm{PM}_{5}, \mathrm{PM}_{2.5}$ concentration after snow was $159.24 \pm 49.18$ (229.16-86.11) $\mathrm{\mu g} / \mathrm{m}^{3}, \quad 156.05 \pm 48.18 \quad(221.87-101.75)$ $\mathrm{\mu g} / \mathrm{m}^{3}, 139.36 \pm 49.88(214.80-77.78) \mu \mathrm{g} / \mathrm{m}^{3}, 124.06 \pm 50.63$ (207.73-56.25) $\mathrm{\mu g} / \mathrm{m}^{3}$, respectively. By comparing the variation of atmospheric particulate matter before and after snow, it shows that the concentration of TSP, $\mathrm{PM}_{10}$, $\mathrm{PM}_{5}, \mathrm{PM}_{2.5}$ after snow were significantly lower than before, all results showed the same variation (Fig. 1), which further improved that the effect of scavenging of kinds of atmospheric particulates by snow is obvious. These results agree with those of studies in Beijing (China) and Logan (Kentucky, USA), the four PMs decreased a lot after the snow event in Beijing and Logan (Guo et al., 2013; Malek et al., 2006). 
Table 1. Characteristics of snow events

\begin{tabular}{|c|c|c|c|c|c|c|c|c|}
\hline Snow Ordinal (time) & Snow Date & $\begin{array}{c}\text { Relative } \\
\text { Humidity } \\
\text { (\%) }\end{array}$ & $\begin{array}{c}\text { Temperat } \\
\text { ure }\left({ }^{\circ} \mathrm{C}\right)\end{array}$ & $\begin{array}{c}24 \mathrm{~h} \\
\text { Snowfall } \\
(\mathrm{mm} / \mathrm{d})\end{array}$ & $\begin{array}{c}\text { Total } \\
\text { Snowfall } \\
(\mathrm{mm})\end{array}$ & $\begin{array}{c}\text { Drying } \\
\text { Time (d) }\end{array}$ & $\begin{array}{l}\text { Duration } \\
\text { (h) }\end{array}$ & $\begin{array}{c}\text { HASI } \\
(\mathrm{mm} / \mathrm{h})\end{array}$ \\
\hline \multirow[t]{3}{*}{ No.1 } & $2013-11-8$ & 99 & $-3 \sim 3$ & 3.7 & 4.8 & 4 & 13 & 0.37 \\
\hline & 2013-11-9 & $94-99$ & $-6 \sim 2$ & 1 & & & & \\
\hline & 2013-11-10 & $92-99$ & $-4 \sim-1$ & 0.1 & & & & \\
\hline \multirow[t]{2}{*}{ No.2 } & $2013-11-20$ & 7399 & $-6 \sim 3$ & 0.1 & 3.9 & 9 & 4 & 0.98 \\
\hline & 2013-11-21 & $81-99$ & $-1 \sim 3$ & 3.8 & & & & \\
\hline \multirow[t]{2}{*}{ No.3 } & $2013-12-18$ & $92-95$ & $-9 \sim 2$ & 0.1 & 2.8 & 4 & 10 & 0.28 \\
\hline & 2013-12-19 & $83-97$ & $-14 \sim-2$ & 2.7 & & & & \\
\hline \multirow[t]{3}{*}{ No.4 } & $2014-1-4$ & $78-84$ & $-23 \sim-17$ & 0.1 & 3.0 & 10 & 6 & 0.50 \\
\hline & $2014-1-5$ & $85-89$ & $-23 \sim-14$ & 0.1 & & & & \\
\hline & 2014-1-6 & $78-86$ & $-20 \sim-9$ & 2.8 & & & & \\
\hline \multirow[t]{2}{*}{ No.5 } & $2014-2-21$ & $60-91$ & $-21 \sim-6$ & 0.2 & 3.2 & 4 & 7 & 0.46 \\
\hline & 2014-2-22 & $60-94$ & $-13 \sim-5$ & 3.0 & & & & \\
\hline \multirow[t]{2}{*}{ No.6 } & $2014-2-24$ & $76-91$ & $-13 \sim-5$ & 6.1 & 6.8 & 1 & 15 & 0.45 \\
\hline & $2014-2-25$ & $50-88$ & $-25 \sim-9$ & 0.7 & & & & \\
\hline \multirow[t]{3}{*}{ No.7 } & $2014-3-9$ & $51-81$ & $-15 \sim-1$ & 0.1 & 2.7 & 11 & 8 & 0.34 \\
\hline & $2014-3-10$ & $79-94$ & $-17 \sim-2$ & 2.5 & & & & \\
\hline & 2014-3-11 & $66-93$ & $-15 \sim-2$ & 0.1 & & & & \\
\hline
\end{tabular}
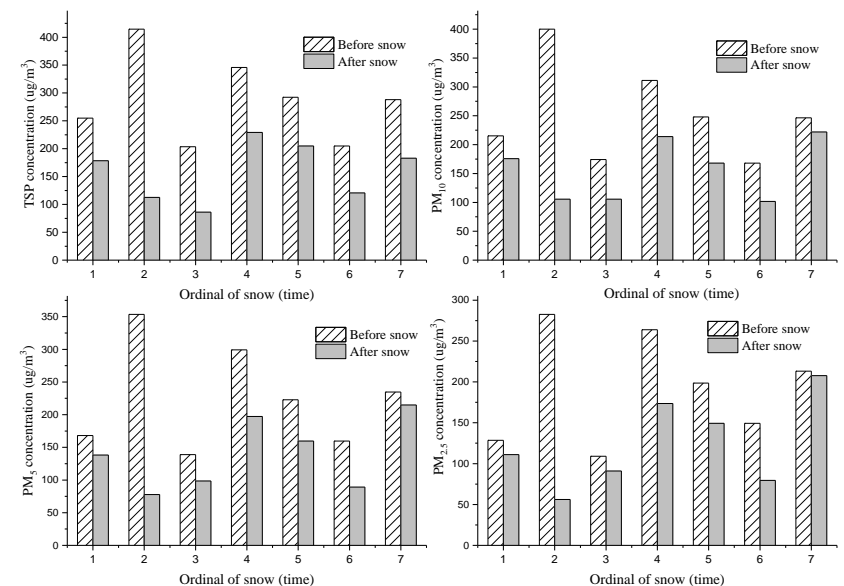

Figure 1. Variations of atmospheric particulates concentration before and after snow

\subsection{Scavenging quantity and scavenging ratio of PM by} snow

In order to discuss scavenging effect of atmospheric particulates by snow deeply, snow scavenging quantity and scavenging ratio were given. They can be expressed by (Pan et al., 2012; Ye et al., 2010),

$$
\begin{aligned}
& \mathrm{M}=\left(\mathrm{C}_{1}-\mathrm{C}_{2}\right) * \mathrm{~V} \\
& \mathrm{P}=\left(\mathrm{M} / \mathrm{C}_{1} * \mathrm{~V}\right) * 100 \%
\end{aligned}
$$

Where $M$ and $P$ is snow scavenging quantity $(\mu \mathrm{g})$ and scavenging ratio, respectively. $C_{1}$ and $C_{2}$ is the concentration of atmospheric particulate before and after snow, respectively $\left(\mu \mathrm{g} / \mathrm{m}^{3}\right) . \quad V$ is the volume of atmosphere $\left(\mathrm{m}^{3}\right)$. $V$ in this study was taken as $1 \mathrm{~m}^{3}$.

The mean scavenging quantity and range (minimum and maximum, in brackets) of TSP, $\mathrm{PM}_{10}, \mathrm{PM}_{5}, \mathrm{PM}_{2.5}$ by snow was 127.07 (76.39-302.08) $\mu \mathrm{g}, 95.83$ (24.65-294.45) $\mu \mathrm{g}$,
85.93 (19.91-275.70) $\mu \mathrm{g}$ and 68.10 (5.46-226.39) $\mu \mathrm{g}$. In general, the highest scavenging quantity of PM by snow was TSP, followed by $\mathrm{PM}_{10}, \mathrm{PM}_{5}$ and $\mathrm{PM}_{2.5}$, except for lower $\mathrm{PM}_{10}$ concentration in No.4 and No.6 snow events (left of Fig. 2). The variations of scavenging quantity of PM in the other five snow events were all consistent with the main scavenging sequence. The pattern of seven snow events such as snow amount, snow intensity, drying time and relative humidity were different from each other, but the variation of scavenging quantity of four PMs in seven snow events were similar. The larger atmospheric particulate was, the higher scavenging quantity was, and vice versa, which indicated that different types of snow had a similar effect of scavenging quantity. The results were similar with the blowing snow study in Antarctica, the blowing snow particles will collect the large ions much more efficiently than smaller ions (Kamra et al., 2009).

The mean scavenging ratio and range (minimum and maximum, in brackets) of TSP, $\mathrm{PM}_{10}, \mathrm{PM}_{5}$, and $\mathrm{PM}_{2.5}$ by snow was 43.12 (29.93-72.86), 34.91 (10.00-73.61), 34.26 (8.48-78.00) and 31.22 (2.56-80.10), respectively. In these snow events, the highest scavenging ratio of $\mathrm{PM}$ by snow was TSP, followed by $\mathrm{PM}_{10}, \mathrm{PM}_{5}$ and $\mathrm{PM}_{2.5}$, which was the same as the variation of the snow scavenging quantity. The smaller particle was, the lower scavenging ratio by snow was. However, in No.2, No.4, No.5 and No.6 snow events, the snow scavenging ratio for four kinds of PMs was similar, it is not consistent with the pattern of scavenging ratio ranking (Fig. 2). 


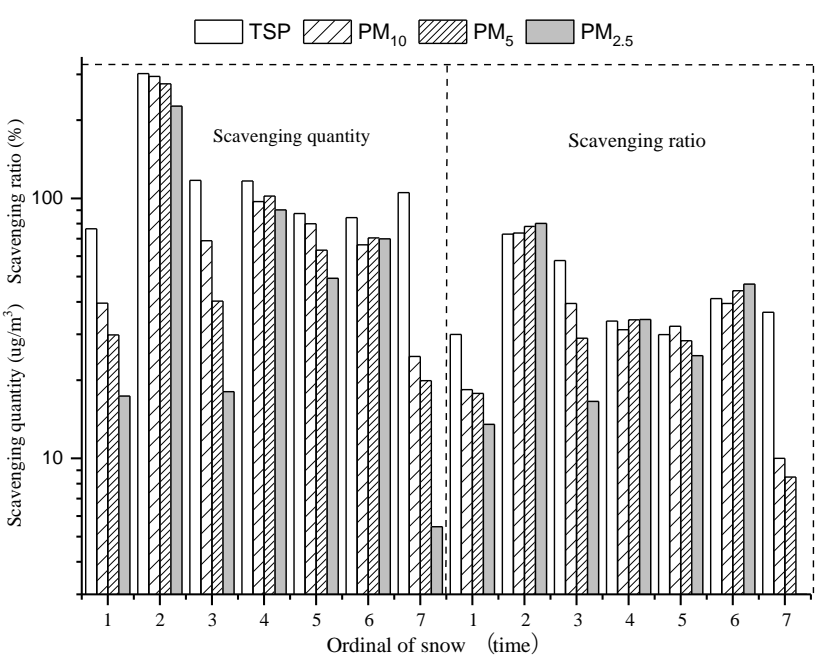

Figure 2. Snow scavenging quantity and scavenging ratio of atmospheric particulates

\subsection{Impact of variation of snow pattern on snow scavenging}

\subsubsection{The relationship between snow pattern and snow scavenging quantity \& ratio}

In a manner of speaking that there is relationship between snow pattern and snow scavenging (Pan et al., 2012). The snow pattern of seven snow events are all different, we analyze the impact of snow pattern on snow scavenging in each of seven snow events.

The variation of scavenging quantity and scavenging ratio of PMs by snow were similar in No.1, No.3 and No.7 snow events. The larger particulate diameter was, the higher snow scavenging quantity and scavenging ratio were, and vice versa (Fig. 2). HASI was low $(<0.37 \mathrm{~mm} / \mathrm{h})$ in No.1, No.3 and No.7 snow events, which indicted that snow scavenging was selective for particulate diameter in light snow event. In other word, in light snow event, the scavenging quantity and scavenging ratio of large particulates was higher, however the scavenging quantity and scavenging ratio of small particulates was lower (Kamra et al., 2009; Nazarenko et al., 2017). Although the snow amount $(3.7 \mathrm{~mm} / \mathrm{d})$ reached moderate snow in first day of No.1 snow event, the snow amount was very low in second and third day $(1 \mathrm{~mm} / \mathrm{d}$ and $0.1 \mathrm{~mm} / \mathrm{d}$, respectively) of No.1 snow event. The low snowfall reduced the scavenging amount/ratio of particles by moderate snow in first day of No.1 snow event and made No.1 snow event pattern like light snow.

Unlike the pattern of snow scavenging quantity and scavenging ratio in No.1, No.3 and No.7 snow events, the variation of scavenging quantity of different PMs in No.2, No.4, No.5 and No.6 snow events were small, and variation of scavenging ratio of them were smaller (Fig. 2).

The highest scavenging quantity and scavenging ratio of atmospheric particulates by snow was No. 2 snow event in seven snow events. The drying time was 9 days, the accumulation of atmospheric particulates was very high (Fig. 2). Atmospheric particulates were hardly scavenged by light snow $(0.1 \mathrm{~mm} / \mathrm{d})$ in first day of No.2 snow event. The particles were greatly scavenged by moderate snow
(3.8 mm/d) with high HASI (snow intensity attained $2 \mathrm{~mm} / \mathrm{h}$ at the last hour) in second day of No.2 snow event, it snowed for 4 hours. The scavenging process indicated that the highest scavenging quantity of PMs in No.2 snow event and the highest scavenging ratio of PMs in seven snow event were attribute to higher snow intensity(Yu et al., 2018), so were the similar effect of snow scavenging of all PMs and the low selectivity. Longer drying time can lead to more atmospheric particulate accumulation, both of them may result in a high value of scavenging quantity or scavenging ratio.

The snow level reached heavy snow $(6.1 \mathrm{~mm} / \mathrm{d})$ in first day of No.6 snow event and lasted 12 hours to midnight, then stopped for an hour, and light snow $(0.7 \mathrm{~mm} / \mathrm{d})$ fell before dawn for 3 hours. The scavenging ratio of PMs in No.6 snow event was high due to the high snow intensity. And the high snow intensity also lead to little variation of scavenging ratio of particles with various diameters (Kamra et al., 2009). Snow intensity of first day in No.6 snow event was the highest in all snow events. However, the snow scavenging effect of No.6 snow event was lower than that of No.2 snow event due to the light snow in second day in No.6 snow event. The light snow relieved high scavenging ratio causing by heavy snow in first day. Besides, the drying time of No.6 snow event is 1 day, it lead to lower accumulation of the PMs (Witkowska and Lewandowska, 2016).

The amount of No.4 and No.5 snow event was not high, respectively. However, the snowing duration was short which lead to high snow intensity (No.4, $0.50 \mathrm{~mm} / \mathrm{h}$; No.5, $0.46 \mathrm{~mm} / \mathrm{h}$ ). In addition, both of the snow amount reached moderate snow on the final day. The scavenging effect of various PM were obvious and the scavenging ratio of different diameters were similar.

\subsubsection{The relationship between snow intensity and scavenging pattern}

The scavenging pattern of No.1, No.3, and No.7 snow events were clearly different from No.2, No.4, No.5 and No. 6 snow events, meanwhile, snow intensity is the most obvious difference between snow patterns. The snow intensity was low $(<0.37 \mathrm{~mm} / \mathrm{h})$ in No.1, No.3, and No.7 snow events, but it was high $(>0.45 \mathrm{~mm} / \mathrm{h})$ in No.2, No.4, No. 5 and No. 6 snow events. The main influencing factors of scavenging ratio of PMs are snow intensity, drying time and snowfall, furthermore, snow intensity is crucial. Generally speaking, the stronger snow intensity was, the higher scavenging ratio of atmospheric particulates was, and vice versa (Fig. 3). Moreover, snow scavenging is selective about different PMs, it depend on snow intensity. The stronger snow intensity was, the lower selectivity was. Stronger snow intensity lead to similar variation of scavenging ratio of different diameters. On the contrary, the weaker snow intensity was, the higher selectivity was, which meant light snow scavenging of large particles was obvious but few for small particles.

Samples were collected in time, the samples can accurately reflect the variation of particles before and after the snow. However, atmospheric particulates 
accumulated during the sampling process, which may interfere with the effect of snow scavenging. In order to proof our results are reasonable, we will continue trial to verify for more snow events. A further study is needed to carry out.

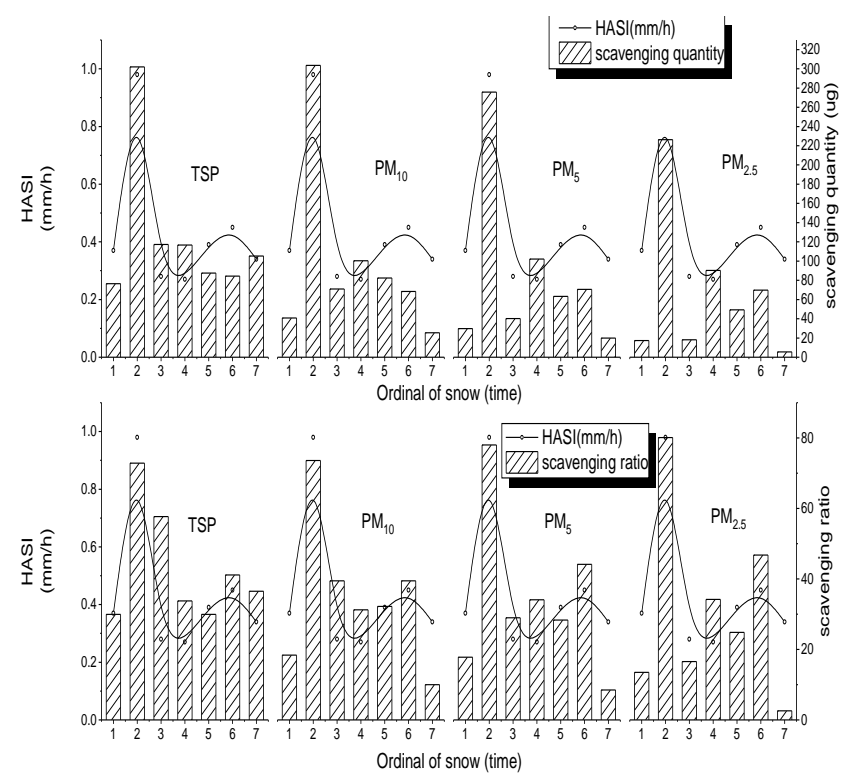

Figure 3. Relationship between snow intensity and scavenging ratio

\section{Conclusions}

The snow scavenging effect on atmospheric particulate is obvious. In general, the highest snow scavenging quantity and scavenging ratio was TSP, followed by $\mathrm{PM}_{10}, \mathrm{PM}_{5}$ and $\mathrm{PM}_{2.5}$. The result indicate that snow can scavenge more large diameter particles but less small particles. The main influencing factors of scavenging ratio of PMs are snow intensity, drying time and snowfall, furthermore, snow intensity is crucial. Heavier snow intensity will increase scavenging ratio of PMs. Moreover, snow scavenging is selective about different PMs, it depend on snow intensity. The stronger snow intensity was, the lower selectivity was. Stronger snow intensity lead to similar variation of scavenging ratio of different diameters. On the contrary, the weaker snow intensity was, the higher selectivity was, which meant scavenging of large particles by light snow was obvious but few for small particles.

\section{Acknowledgments}

This research was supported by National Natural Science Foundation (41461090) and Hainan Natural Science Foundation Innovation Team (2017CXTD006). The authors thank Department of Chemistry and Applied Chemistry of Changji University, Tianyu Han, Zhibo Wu, Guanglin Zhu, Huanhuan Zhang, Xiaoxia Wang and others in the Department of Chemistry and Applied Chemistry of Changji University for helping to complete the sampling and experimental work.

\section{References}

Cereceda-Balic F., Palomo-Marín M.R., Bernalte E., Vidal V., Christie J., Fadic X., Guevara J.L., Miro C. and Gil P. (2012),
Impact of Santiago de Chile urban atmospheric pollution on anthropogenic trace elements enrichment in snow precipitation at Cerro Colorado, central Andes, Atmospheric Environment, 47(3), 51-57.

Chate D.M. (2005), Study of scavenging of submicron-sized aerosol particles by thunderstorm rain events, Atmospheric Environment, 39(35), 6608-6619.

Chen R.J., Peng R.D., Meng X., Zhou Z.J., Chen B.H. and Kan H.D. (2013), Seasonal variation in the acute effect of particulate air pollution on mortality in the China Air Pollution and Health Effects Study (CAPES), Science of the Total Environment, 450-451, 259-265.

Francová A., Chrastný V., Šillerová H., Vítková M., Kocourková J. and Komárek M. (2016), Evaluating the suitability of different environmental samples for tracing atmospheric pollution in industrial areas, Environmental Pollution, 220, 286-297.

Freije A.M. (2015), Heavy metal, trace element and petroleum hydrocarbon pollution in the Arabian Gulf: Review, Journal of the Association of Arab Universities for Basic and Applied Sciences, 17, 90-100.

Grantz D.A., Garner J.H. and Ohnson D.W. (2003), Ecological effects of particulate matter, Environment International, 29(2-3), 213-239.

Guo E.G., Cheng W., Guang-Fa Q. and Yu C. (2013), Influence of typical weather conditions on the airborne particulate matters in urban forests in northern China, China Environmental Science, 33(7), 1185-1198.

Gunawardena J., Egodawatta P., Ayoko G.A. and Goonetilleke A. (2013), Atmospheric deposition as a source of heavy metals in urban stormwater, Atmospheric Environment, 68(1), 235242.

Hu X., Zhang Y., Ding Z.H., Wang T.J., Lian H.Z., Sun Y.Y. and Wu J.C. (2012), Bioaccessibility and health risk of arsenic and heavy metals ( $\mathrm{Cd}, \mathrm{Co}, \mathrm{Cr}, \mathrm{Cu}, \mathrm{Ni}, \mathrm{Pb}, \mathrm{Zn}$ and $\mathrm{Mn}$ ) in TSP and $\mathrm{PM}_{2.5}$ in Nanjing, China, Atmospheric Environment, 57(57), 146-152.

Kamra A.K., Siingh D. and Pant V. (2009), Scavenging of atmospheric ions and aerosols by drifting snow in Antarctica, Atmospheric Research, 91(2), 215-218.

Lee B.K., Park G.H. (2010), Characteristics of heavy metals in airborne particulate matter on misty and clear days, Journal of Hazardous materials, 184, 406-416.

Lima A.T., Safar Z. and Loch J.P. (2014), Evaporation as the transport mechanism of metals in arid regions, Chemosphere, 111, 638-647.

Liu Y., Tian F.F., Liu C. and Zhang L. (2015), Platinum group elements in the precipitation of the dry region of Xinxiang and factors affecting their deposition to land: the case of changii city, China, Atmospheric Pollution Research, 6(2), 178-183

Liu Y.Y. and Wang Y.J. (2011), Effect of climate conditions in arid area on accumulation of $\mathrm{Pd}, \mathrm{Rh}$ in dust and soil from road environment, China Environmental Science, 31(9), 15281532.

Malek E., Davis T., Martin R.S. and Silva P.J. (2006), Meteorological and environmental aspects of one of the worst national air pollution episodes (January, 2004) in Logan, cache valley, Utah, USA, Atmospheric Research, 79(2), 108-122. 
Mamtimin B. and Meixner F.X. (2011), Air pollution and meteorological processes in the growing dryland city of Urumqi (Xinxiang, China), Science of the Total Environment, 409(7), 1277-1290.

Melaku S., Morris V., Raghavan D. and Hosten C. (2008), Seasonal variation of heavy metals in ambient air and precipitation at a single site in Washington, DC, Environmental Pollution, 155(1), 88-98.

Nazarenko Y., Fournier S., Kurien U., Rangelalvarado R.B., Nepotchatykh O., Seers P. and Ariya P.A. (2017), Role of snow in the fate of gaseous and particulate exhaust pollutants from gasoline-powered vehicles, Environmental Pollution, 223, 665-675

Pan B.F., Zhao Y.L., Li J.J. and Wang R.B. (2012), Analysis of the scavenging efficiency on $\mathrm{PM}_{2.5}$ concentration of some kinds of meteorological factors, Environmental Science \& Technology, 25(6), 41-44.

Schleicher N.J., Norra S., Chai F., Chen Y., Wang S., Cen K., Yu Y. and Stüben D. (2011), Temporal variability of trace metal mobility of urban particulate matter from Beijing - A contribution to health impact assessments of aerosols, Atmospheric Environment, 45(39), 7248-7265.

Shan G., Chen X. and Zhu L. (2015), Occurrence, fluxes and sources of perfluoroalkyl substances with isomer analysis in the snow of northern China, Journal of Hazardous Materials, 299, 639-646.

Singh M.P., Singh V.K., Patel D.K., Tandon P.K., Gaur J.S., Behari J.R. and Yadav S. (2010), Face mask application as a tool to diminish the particulate matter mediated heavy metal exposure among citizens of Lucknow, India, Science of the Total Environment, 408(23), 5723-5728.

Taniyasu S., Yamashita N., Moon H.B., Kwok K.Y., Lam P.K., Horii Y., Petric G. and Kannan K. (2013), Does wet precipitation represent local and regional atmospheric transportation by perfluorinated alkyl substances?, Environment International, 55(4), 25-32.

Valiulis D., Čeburnis D., Šakalys J. and Kvietkus K. (2002), Estimation of atmospheric trace metal emissions in Vilnius city, Lithuania, using vertical concentration gradient and road tunnel measurement data, Atmospheric Environment, 36(39-40), 6001-6014.

Vijayanand C., Rajaguru P., Kalaiselvi K., Panneer Selvam K. and Palanivel M. (2008) Assessment of heavy metal contents in the ambient air of the Coimbatore city, Tamilnadu, India, Journal of Hazardous materials, 160, 548-553.

Wania F., Hoff J.T., Jia C.Q. and Mackay D. (1998), The effects of snow and ice on the environmental behaviour of hydrophobic organic chemicals, Environmental Pollution, 102(1), 25-41.

Witkowska, A., and Lewandowska, A.U. (2016). Water soluble organic carbon in aerosols (pm1, pm2.5, pm10) and various precipitation forms (rain, snow, mixed) over the southern baltic sea station, Science of the Total Environment, 573, 337-346.

Ye Y.B., Zhang W., Hu D., Ou L.B. and Wang X.J. (2010), Scavenging of airborne polycyclic aromatic hydrocarbons by rainfall in urban area. China Environmental Science, 30(7), 985-991.

Yu F., Wang Q, Yan Q.S, Jiang N., Wei J.H., Wei Z.Y. and Yin S.S. (2017), Particle size distribution, chemical composition and meteorological factor analysis: A case study during wintertime snow cover in Zhengzhou, China, Atmospheric Research, 202, 140-147. 